\title{
WITHIN GROUP AND BETWEEN GROUP COMPARISONS OF POLITICAL AND APOLITICAL VOTERS OF BANGLADESH WITH PERSONALITY DIMENSION OF AUTHORITARIANISM
}

\author{
Syed Md. Ziauddin \\ Department of Psychology, University of Rajshahi, Rajshahi 6205, Bangladesh. \\ Email: zia_psy@yahoo.com
}

\begin{abstract}
The study attempted to measure authoritarianism, as related to political-apolitical group composition, male-female gender recognition and urban-rural residential background of the subjects. Kool's (1980) authoritarian scale was used. A total of 320 subjects were equally divided into political and apolitical groups. Thus a $2 \times 2 \times 2$ factorial design involving 2 levels of group composition (political vs. apolitical), 2 levels of gender (male vs. female) and 2 levels of residential background (urban vs. rural) was used. Results were analyzed using t-tests on the scores of authoritarian scale. Although no significant difference was obtained between political and apolitical groups $(\mathrm{N}=160)$, within-group comparisons revealed that urban females of political affiliation were more authoritarian than the urban males, rural males and rural females ( $\mathrm{N}=40$ for each). Again urban females of apolitical group were found more authoritarian than urban males, rural males and rural females ( $\mathrm{N}=40$ for each). A comparison between groups of political and apolitical subjects revealed that urban females of political group were more authoritarian than rural males and rural females of apolitical groups $(\mathrm{N}=40$ for each). On the other hand, urban females of apolitical group were found more authoritarian than urban males, rural males and rural females of political affiliation. Irrespective of gender, political urban subjects were more authoritarian than apolitical rural subjects $(\mathrm{N}=80)$ while apolitical urban subjects were more authoritarian than political rural subjects $(\mathrm{N}=80)$.
\end{abstract}

Key words: Political and apolitical voters, authoritarianism, personality dimension, Kool's authoritarian scale

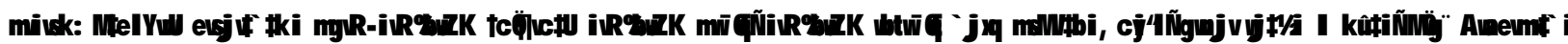

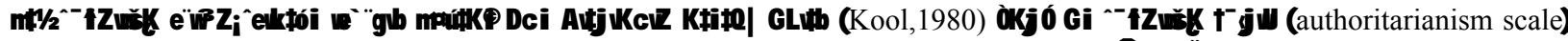

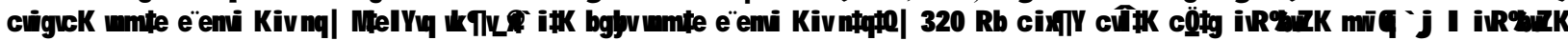

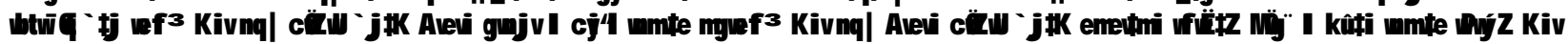

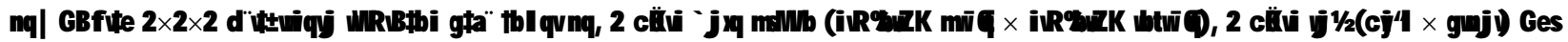

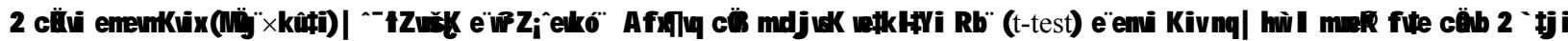

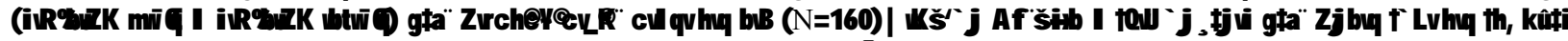

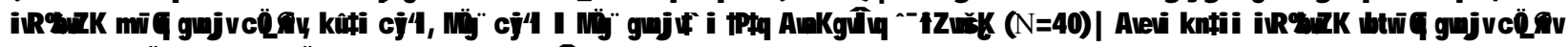

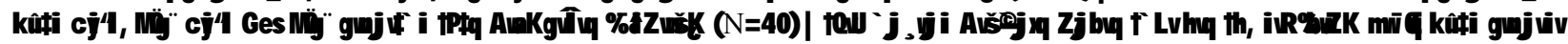

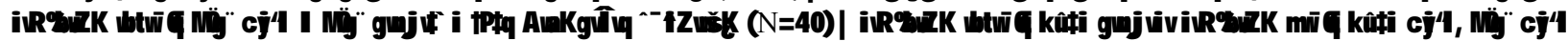

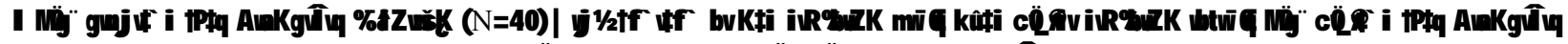

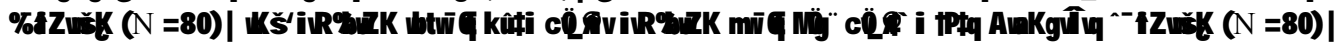

\section{Introduction}

Authoritarianism is a personality trait commonly operationally defined in terms of (a) a high degree of compliance with socially-accepted authorities; (b) aggressiveness toward persons that is believed to be sanctioned by established authorities; and (c) a high degree of adherence to social conventions believed to be favoured by society and established authority (Altemeyer 1996). The two primary instruments for measuring authoritarianism are the $\mathrm{F}$ (Fascism) scale (Adorno et al. 1950) and the RWA (Right-Wing Authoritarianism) scale (Altemeyer 1981, 1988, 1996).

Characteristically authoritarians are less likely than most people to demonstrate self-awareness (Altemeyer 1996) and are more likely to favour religious beliefs over scientific data when the two appear to be in conflict (Westman et al. 2000). They exhibit more selfreported fear than the general population (Eigenburger 1999, Heaven and Conners 2001). Again, according to Kool (1980) authoritarian attitudes express submissiveness towards his superiors and domineering towards his subordinates. Following this differential attitudinal pattern in personality, Kool (1980) developed the authoritarian scale. He borrowed the items from $F$ scale (Adorno et al. 1950), dogmatism scales (Rokeach 1960) and open minded scale (Haiman 1954) and developed his authoritarian scale for using it in Indian context. The present study agreed upon Kool's (1980) conceptions and accepted his tools for measuring authoritarianism. In Bangladesh, most of the social, economic and political privileges (Huq and Khatun 1988) are enjoyed by male persons and females are deprived of economic, political and social gains. These feelings of 
deprivation in females have several consequences in the personality development. One such consequence might be the authoritarian personality syndrome in Bangladeshi women. This has been supported by empirical study (Ara et al. 1985). The high authoritarianism in female in the context of Bangladesh might be understood in these theoretical perspectives.

The present study has both theoretical and applied implications. It is hoped that the study would broaden the theoretical horizon of social psychology about personality. In addition, there is a certain specific reason for conducting this study. This study is a purely scientific curiosity for assessing the personality of Bangladeshi students. The broad objective of the study was to conduct an empirical investigation of one psychological dimensions of personality, i.e. authoritarianism, of political and apolitical voters in Bangladesh as related to some demographic variables. Therefore, the present study had the following objectives: (i) To study similarities and differences in voters as related to authoritarianism dimension of personality; (ii) To study male-female differences in the authoritarian dimension of personality; and (iii) To study the differences in the personality variable, like authoritarianism, as related to urban-rural residential background of the voters. As the experiment was exploratory in nature, no specific hypothesis was formulated.

\section{Materials and Methods}

Experimental design: The study was designed to measure within and between group differences among politicalapolitical, urban-rural and male-female groups of voters in the personality dimension authoritarianism. Hence, for the purpose of integration among the variables, a $2 \times 2 \times 2$ factorial analysis consisting of two levels of group composition (political/apolitical), two levels of sex (male/female) and two levels of residential background (urban/rural) was computed on each of the specific variables. Mean differences were computed on each variable separately. Student's t-tests were used for the purpose. The general purpose of the design was to study personality factor of authoritarianism as related to some demographic variables like political-apolitical, urban-rural, and male-female characteristics of the participants.

Background and characteristics of the sample settings: Two students' samples viz. political and apolitical were utilized for the collection of data. Both the group of subjects was collected from post-graduate classes of University of Rajshahi. The subjects were equally divided into male and female genders, and urban and rural origin. The respondents were between 21 and 25 years of age, and were registered as voters. A total of 320 subjects were selected for the study. They were further divided equally into political and apolitical groups using an activism criteria questionnaire developed by Ara (1983). The subjects scoring between
13 and 16 were considered as political and those between 0 and 4 as apolitical persons.

Adaptation of Ara's (1983) Activism Criteria Questionnaire (ACQ): The ACQ contains 16 items relating to activism and non-activism. A total score for sixteen items ranged from $\mathrm{O}$ to 16 , indicating the higher scores for political and lower scores for the apolitical persons. The break-up of sample of the present study is given in the following table.

Table 1. Sample break-up according to political groups, residential background and gender of the subjects.

\begin{tabular}{|c|c|c|c|c|c|}
\hline $\begin{array}{c}\text { Residential } \\
\text { background }\end{array}$ & \multicolumn{2}{|c|}{ Political group } & \multicolumn{2}{|c|}{$\begin{array}{c}\text { Apolitical } \\
\text { group }\end{array}$} & Total \\
\hline & Male & Female & Male & Female & \\
\hline Urban & 40 & 40 & 40 & 40 & 160 \\
Rural & 40 & 40 & 40 & 40 & 160 \\
\hline Total & 80 & 80 & 80 & 80 & 320 \\
\hline
\end{tabular}

Selection of instruments: Bengali adaptation of Kool's (1980) authoritarian scale as developed by Ara (1983) by the method of expert judges was used, where testretest reliability was 0.54 . The validity of this scale was found by correlating it with Freedman's 1965) authoritarianism scale at 0.33 . The five point scale had the highest and the lowest possible scores of $(23 \times 5)$ $=115$ and $(23 \times 1)=23$, respectively.

Data collection: All of the 320 respondents were collected from post-graduate classes of different Faculties of Rajshahi University. Political respondents were contacted through political group members. The investigator himself approached the non-political respondents. Female subjects were approached through female volunteers.

Administration of the tests: The subjects were asked to express their opinions about each statement. The response of each subject was required to give on 5-point scale, ranging from strongly agree to strongly disagree. Thus respondents were asked to put a $(\sqrt{ })$ mark on any one of five alternatives given against each statement.

\section{Results and Discussion}

Within-group (political) comparisons: Results presented in Table 2 revealed that political urban females (PUF) were significantly more authoritarian in comparison to political urban males, PUM $(\mathrm{t}=3.53 ; \mathrm{P}<0.01$ at $39 \mathrm{df})$, political rural males, PRM $(\mathrm{t}=3.92 ; \mathrm{P}<0.01$ at $39 \mathrm{df})$ and political rural females, $\mathrm{PRF}(\mathrm{t}=3.83 ; \mathrm{P}<0.01$ at 39 df). All other comparisons, however, were not significant statistically. 
Table 2. Within-group comparisons between political group of students involving residential background (urban and rural) and gender (male and female) on the scores of authoritarian scale $(\mathrm{N}=40)$

\begin{tabular}{|c|c|c|c|c|c|}
\hline Subjects & Mean \pm SD & PUM & PUF & PRM & PRF \\
\hline PUM & $75.92 \pm 6.19$ & - & $3.53^{* *}$ & $1.15 \mathrm{~ns}$ & $0.03 \mathrm{~ns}$ \\
PUF & $80.62 \pm 5.58$ & & - & $3.92^{* *}$ & $3.83^{* *}$ \\
PRM & $73.87 \pm 9.19$ & & & - & $1.51 \mathrm{~ns}$ \\
PRF & $75.87 \pm 5.46$ & & & & - \\
\hline
\end{tabular}

$\mathrm{PUM}=$ political urban male; $\mathrm{PUF}=$ political urban female; $\mathrm{PRM}=$ political rural male; $\mathrm{PRF}=$ political rural female; $* *=\mathrm{P}<0.01$ by t-tests at $39 \mathrm{df} ; \mathrm{ns}=$ not significant.

Table 3. Within-group comparisons between apolitical group of students involving residential background (urban and rural) and gender (male and female) on the scores of authoritarian scale $(\mathrm{N}=40)$

\begin{tabular}{|c|c|c|c|c|c|}
\hline Subjects & Mean \pm SD & AUM & AUF & ARM & ARF \\
\hline AUM & $75.27 \pm 6.46$ & - & $3.58^{* *}$ & $0.36 \mathrm{~ns}$ & $0.31 \mathrm{~ns}$ \\
AUF & $79.92 \pm 4.93$ & & - & $2.73^{*}$ & $4.40^{* *}$ \\
ARM & $75.87 \pm 7.89$ & & & - & $1.68 \mathrm{~ns}$ \\
ARF & $74.85 \pm 5.25$ & & & - \\
\hline
\end{tabular}

$\mathrm{AUM}=$ apolitical urban male; $\mathrm{AUF}=$ apolitical urban female; $\mathrm{ARM}=$ apolitical rural male; $\mathrm{ARF}=$ apolitical rural female; $*=\mathrm{P}<0.05$ and $* *=\mathrm{P}<0.01$ by t-tests at $39 \mathrm{df} ; \mathrm{ns}=$ not significant.

Table 4. Between-group comparisons of political and apolitical subjects in various combinations of gender and residential background on the scores of authoritarian scale $(\mathrm{N}=40)$.

\begin{tabular}{|c|c|c|c|c|c|}
\hline Ss & Political & Ss & Apolitical & t-values & Probabilities \\
\hline & Mean \pm SD & & Mean \pm SD & & \\
\hline PUM & $75.92 \pm 6.19$ & AUF & $79.92 \pm 4.93$ & 3.15 & $0.01^{* *}$ \\
PUF & $80.62 \pm 5.58$ & AUM & $75.27 \pm 6.46$ & 3.90 & $0.01^{* *}$ \\
PUF & $80.62 \pm 5.58$ & ARM & $75.87 \pm 7.89$ & 3.06 & $0.01^{* *}$ \\
PUF & $80.62 \pm 5.58$ & ARF & $74.85 \pm 5.24$ & 4.73 & $0.01^{* *}$ \\
PRM & $73.87 \pm 9.19$ & AUF & $79.92 \pm 4.93$ & 3.62 & $0.01^{* *}$ \\
PRF & $75.87 \pm 5.46$ & AUF & $79.92 \pm 4.93$ & 3.43 & $0.01^{* *}$ \\
\hline
\end{tabular}

$\mathrm{Ss}=$ subjects; prefix P refers to political and A refers to apolitical; $\mathrm{UM}=$ urban males; $\mathrm{UF}=$ urban females; $\mathrm{RM}=$ rural males; $\mathrm{RF}=$ rural females; $* *=\mathrm{P}<0.01$ at $39 \mathrm{df}$.

Within-group (apolitical) comparisons: Results on apolitical comparisons within-group (Table 3) showed that apolitical urban females (AUF) significantly more authoritarian compared to apolitical urban males, AUM $(\mathrm{t}=3.58 ; \mathrm{P}<0.01$ at $39 \mathrm{df})$, apolitical rural males, ARM $(\mathrm{t}=2.73 ; \mathrm{P}<0.05$ at $39 \mathrm{df})$ and apolitical rural females, ARF $(\mathrm{t}=4.40 ; \mathrm{P}<0.01$ at $39 \mathrm{df})$. The remaining comparisons did not reveal any significant differences.

Between-group (political-apolitical) comparisons: Comparisons between political and apolitical groups (Table 4) showed that AUF expressed significantly more authoritarianism $(\mathrm{t}=3.15$, df $39, \mathrm{P}<0.01)$ as compared to PUM subjects. PUF, on the other hand, exhibited significantly more authoritarianism $(\mathrm{t}=3.06$ $\mathrm{df}=39, \mathrm{P}<0.01)$ in comparison with ARM. Again PUF showed significantly more authoritarianism $(\mathrm{t}=4.73$, df $39, \mathrm{P}<0.01)$ as compared to ARF. It was also found that AUF exhibited significantly more authoritarianism $(\mathrm{t}=$
3.62, df 39, $\mathrm{P}<0.01)$ as compared to PRM. Furthermore, AUF were found significantly more authoritarian $(\mathrm{t}=3.43, \mathrm{df}=39, \mathrm{P}<0.01$ compared to PRF counterparts.

The results presented in Table 5 suggest that political females $(\mathrm{PF})$ expressed significantly more authoritarian attitudes $(\mathrm{t}=2.14$, $\mathrm{df}=79, \mathrm{P}<0.05)$ compared to their political male (PM) counterparts. An inspection of the mean scores shows that irrespective of urban-rural background, both PM and PF obtained authoritarian scores above mid-point (69). Again, regardless of male-female division, PU and PR subjects obtained scores above midpoint, indicating both the groups as authoritarian.

In Table 6, group comparisons have been worked out between AM-AF and AU-AR where AF exhibited significantly higher authoritarianism $(\mathrm{t}=2.01, \mathrm{df}=79$, $\mathrm{P}<$ 0.05) as compared to AM. 
Table 5. Group comparisons between PM-PF and PU-PR on the scores of authoritarian scale $(\mathrm{N}=80)$.

\begin{tabular}{|c|c|c|c|c|}
\hline Ss & Mean \pm SD & t-values & $\begin{array}{c}\text { Level of } \\
\text { significance }\end{array}$ & $\begin{array}{c}\text { Groups } \\
\text { compared }\end{array}$ \\
\hline PM & $74.89 \pm 9.38$ & & & \\
PF & $78.24 \pm 10.04$ & 2.14 & $\mathrm{P}<0.05^{*}$ & PM vs. PF \\
PU & $78.27 \pm 12.77$ & & & PU vs. PR \\
\hline PR & $74.87 \pm 11.65$ & 1.75 & ns & PU
\end{tabular}

$\mathrm{PM}=$ political males; $\mathrm{PF}=$ political females; $\mathrm{PU}=$ political urban; $\mathrm{PR}=$ political rural; $\mathrm{t}$-values are at $79 \mathrm{df}$; $\mathrm{ns}=$ not significant.

Inspection of mean scores showed that both AM and AF subjects obtained scores higher than mid-point (69), indicating both the groups as authoritarian in personality characteristics regardless of their urban-rural background. However, AF subjects were found more authoritarian in comparison to AM counterparts. Moreover, both AU and AR subjects, irrespective of their gender identity obtained scores above mid-point, which indicated that both the groups were authoritarian in personality characteristics.

Table 6. Showing Group comparisons between AM-AF and AU-AR on the scores of authoritarian scale $(\mathrm{N}=80)$.

\begin{tabular}{|c|c|c|c|c|}
\hline Ss & Mean \pm SD & $\begin{array}{c}\mathrm{t}- \\
\text { value }\end{array}$ & $\begin{array}{c}\text { Level of } \\
\text { significance }\end{array}$ & $\begin{array}{l}\text { Groups } \\
\text { compared }\end{array}$ \\
\hline AM & $75.57 \pm 6.17$ & 201 & $\mathrm{P}<005$ & $\mathrm{AM}$ vs. $\mathrm{AF}$ \\
\hline $\mathrm{AF}$ & $77.38 \pm 5.19$ & & & \\
\hline $\mathrm{AU}$ & $77.59 \pm 8.43$ & 158 & $\mathrm{n}_{\mathrm{s}}$ & AU vs. AR. \\
\hline AR & $75.34 \pm 9.38$ & 1.58 & n.s & \\
\hline
\end{tabular}

$\mathrm{Ss}=$ subjects; $\mathrm{AM}=$ apolitical males; $\mathrm{AF}=$ apolitical females; $\mathrm{AU}=$ apolitical urban; $\mathrm{AR}=$ apolitical rural; t-values are at $79 \mathrm{df}$.

The results shown in Table 7 revealed that AF were significantly more authoritarian $(\mathrm{t}=2.93$, df $79, \mathrm{P}<$ 0.01 ) as compared to PM. Similarly, PF subjects were significantly more authoritarian $(\mathrm{t}=2.87, \mathrm{df}=79, \mathrm{P}<$ 0.01 ) in comparison with the AMs. In case of urbanrural comparisons it was found that PUs were significantly more authoritarian $(\mathrm{t}=2.33$, df $=79, \mathrm{P}<$ 0.05 ) as compared to their AR counterparts. Again AUs were found significantly more authoritarian $(\mathrm{t}=2.39$, df $=79, \mathrm{P}<0-05)$ than the PRs. A further inspection of mean scores showed that regardless of urban-rural background, PFs obtained highest score than AFs, AMs and PMs. However, all the groups scored higher than mid-point (69), each indicating authoritarian personality. Similarly, regardless of gender parity, PUs scored the highest, followed by AUs, ARs and PRs. However, all the groups scored higher than mid-point (69), indicating their authoritarian personalities.

Table 7. Group comparisons between political and apolitical subjects on gender division and residential background on the scores of authoritarian scale $(\mathrm{N}=80)$.

\begin{tabular}{|c|c|c|c|c|c|}
\hline Ss & Political & Ss & Apolitical & $\begin{array}{c}\text { t- } \\
\text { values }\end{array}$ & P \\
\hline & Mean \pm SD & & Mean \pm SD & & \\
\hline PM & $74.89 \pm 9.38$ & AF & $77.38 \pm 5.19$ & 2.93 & $0.01^{* *}$ \\
PF & $78.24 \pm 10.04$ & AM & $75.57 \pm 6.17$ & 2.87 & $0.01^{* *}$ \\
PU & $78.27 \pm 12.77$ & AR & $75.34 \pm 9.38$ & 2.33 & $0.05^{*}$ \\
PR & $74.87 \pm 11.65$ & AU & $77.59 \pm 8.43$ & 2.39 & $0.05^{*}$ \\
\hline
\end{tabular}

$\mathrm{Ss}=$ subjects; $\mathrm{PM}=$ political males; $\mathrm{PF}=$ political females; $\mathrm{PU}=$ political urban; $\mathrm{PR}=$ political rural; all t-values are at $79 \mathrm{df} ; \mathrm{P}=$ Probabilities.

Finally, regardless of gender and residential background, group comparisons were also computed between political $(\mathrm{N}=80)$ and apolitical $(\mathrm{N}=80)$ subjects, where the groups did not differ significantly $(\mathrm{t}=0.14 ; \mathrm{df}=159 ; \mathrm{P}>0.05)$. However, an inspection of the mean scores showed that both political $(76.57 \pm 6.30)$ and apolitical (76.47 \pm 6.31$)$ subjects scored above mid point (69), indicating their authoritarian personalities.

A wide array of complex findings has been obtained through the present study. The study was basically exploratory in nature, revealing the relationship between personality and politics, which can be related to a number of previous theoretical and empirical research findings (Ray 1979, 1982, 1984; Ray and Lovejoy 1983; Stone et al. 1985; Kadem et al. 1987; Goertzel 1987). One distinctive feature of the present authoritarianism is that both political and apolitical females of urban origin expressed highest authoritarian personality characteristics as compared to their male counterparts. It is obvious in our prevailing society that most of the social, economic and political privileges are enjoyed by males, whereas females are deprived from economic, political and social gains (Huq and Khatun 1988). In a words, females may be identified as deprived groups in the society. One such consequence might be the authoritarian personality syndrome in Bangladeshi women. This has been supported by an empirical study by Ara et al. (1985). The findings of the study have reflected these characteristics by identifying females as authoritarian in personality composition. Researchers like Narby et al. (1993) and Altemeyer (1996) appear to have followed the consideration.

The present study's main focus was on authoritariannon-authoritarian dimensions of personality. The effects of these dependent variables were studied in the context of political-apolitical group composition, male-female categorization and urban-rural division. The results revealed differential identification in authoritarianism dimension of personality. There might be a characteristic feature of feminine, rural residential background and apolitical self identification. It is therefore suggested that several follow-up studies should be conducted to understand these personality variables. 


\section{Conclusion}

Political urban females were found significantly more authoritarian as compared to political urban males, rural male and rural females. Apolitical urban females were also significantly more authoritarian as compared to apolitical urban males, rural male and rural females. Again, political urban females were more authoritarian as compared to apolitical rural males and rural females. Likewise, apolitical urban females were more authoritarian as compared to political urban males, rural males and rural females. Moreover, political females were more authoritarian than political males and apolitical females were more authoritarian than apolitical males. Apolitical females, however, were more authoritarian than political males and political females were more authoritarian than apolitical males. Similarly, political urban subjects were more authoritarian than apolitical rural subjects, while political urban subjects were more authoritarian than political rural ones. But remarkably, no significant difference was obtained between overall political and apolitical groups of subjects.

\section{References}

Adorno TW, Frenkel-Brunswick E, Levinson PJ and Sanford RN. 1950. The Authoritarian Personality. Harper \& Row Publishers, NY.

Altemeyer B.1981. Right-wing Authoritarianism. The University of Manitoba Press, Manitoba.

Altemeyer B. 1988. Enemies of Freedom. Jossey-Bass Publishers, San Francisco, CA.

Altemeyer B. 1996. The Authoritarian Specter. Harvard University Press, Cambridge, MA.

Ara S.1983. A Comparative Study of Socio-political Attitudes of Activists of India and Bangladesh, Unpubl. PhD Thesis, Department of Psychology, University of Allahabad, India.

Ara S, Huq MM and Jahan RA. 1985. The psychological functioning in male and female for right-left political ideologies. Rajshahi Univ. Studies (Part B) 13: 147-157.

Eigenburger ME. 1999. Fear as a correlate of authoritarianism. Psychol. Reports 83: 1395-1409.

Freedman, HE. 1965. Selective exposure. In: Advances in Experimental Social Psychology (Berkowitz L. ed.), 2. Academy Press, New York.
Goertzel TC. 1987. Ideological consistency and issue voting in 1980. J. Pol. Military Sociol. 9: 197-214.

Haiman FS.1954. A revised scale of measurement of open mindedness. Speech Monograph 31: 97-102.

Heaven PC and Conners JR. 2001. A note on the value correlates of social dominance-orientation and rightwing authoritarianism. Personality and Individual Differences 31: 925-930.

Huq MM and Khatun RA. 1988. A study of fraternal relative deprivation as related to sex and residential background. Rajshahi Univ. Studies (Part B) XVI: 173-180.

Kadem P, Bilu A and Cohen Z. 1987. Dogmatism, ideology and right-wing radical activity. Pol. Psychol. 8: 1.

Kool VK. 1980. Measures of Authoritarianism and Hostility. Himalaya Publ. House, Bombay, India.

Milgram S. 1974. Obedience to Authority. Harper \& Row Publishers, New York.

Narby DJ, Cutler BL and Moran, G.1993. A meta-analysis of the association between authoritarianism and jurors' perceptions of defendant culpability. J. Appl. Psychol. 78: $34-4$

Ray JJ. 1979. Does authoritarianism of personality go with conservatism? Australian J. Psychol. 117: 33-44.

Ray JJ. 1982. Authoritarianism/libertarianism as the second dimension of social attitudes. J. Social Psychol. 117: 33-44.

Ray JJ. 1984. Alternatives to the F scale in the measurement of authoritarianism: A catalog. J. Social Psychol. 122: 105-119.

Ray JJ and Lovejoy FH.1983. Behavioural validity of some recent measures of authoritarianism. J. Social Psychol. 120: 91-99.

Rokeach M. 1960. The Open and Closed Mind. Basic Books, New York.

Stone WF, Ommundsen TR and Williams S. 1985, The structure of ideology in Norway and the United States. J. Social Psychol. 125: 169-179.

Westman AS, Willink J and McHoskey JW. 2000. On perceived conflicts between religion and science: The role of fundamentalism and right-wing authoritarianism. Psychol. Reports 86: 379-385.

Wilson CD and Patterson JR.1968. A new measure of conservatism. British J. Social Psychol. 7: 264-269.

Manuscript received 2 May 2010 and revised 11 December 2010. 